\title{
Variability of the groundwater sulfate concentration in fractured rock slopes: a tool to identify active unstable areas
}

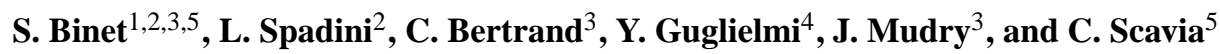 \\ ${ }^{1}$ Institut des Sciences de la Terre d'Orléans, ISTO, UMR 6113, Université d'Orléans, CNRS/INSU, Université François \\ Rabelais, Tours, Campus Géosciences, 1A, rue de la Férollerie, 45071 Orléans cedex 2, France \\ ${ }^{2}$ Laboratoire de Géophysique interne et tectonophysique, LGIT, UMR 5559, Université Joseph Fourier, CNRS/INSU, \\ Observatoire de Grenoble, BP 53, 38041 Grenoble, France \\ ${ }^{3}$ Laboratoire de Chrono-Environnement, LCE, UMR 6249, Université de Franche-Comté, CNRS/INSU France \\ ${ }^{4}$ GéoSciences Azur (GA), UMR6526, CNRS/INSU/IRD, UR082, Observatoire de la Cote d'Azur, Université de Nice \\ Sophia-Antipolis, Université Pierre et Marie Curie, Paris VI, 250 rue A. Einstein, 06560 Valbonne, France \\ ${ }^{5}$ Dipartemento Ingegneria Strutturale e Geotecnica, DIST, Politecnico di Torino, Corso Duca Abruzzi 24, 10129 Torino, Italy
}

Received: 29 June 2009 - Published in Hydrol. Earth Syst. Sci. Discuss.: 6 August 2009

Revised: 29 October 2009 - Accepted: 7 November 2009 - Published: 8 December 2009

\begin{abstract}
Water chemical analysis of 100 springs from the Orco and the Tinée valleys (Western Italy and Southern France) and a 7 year groundwater chemistry monitoring of the 5 main springs were performed. All these springs drain from crystalline rock slopes. Some of these drain from currently active gravitational slope deformations.

All groundwaters flowing through presently unstable slopes show anomalies in the sulfate concentrations compared to stable aquifers. Particularly, an increase of sulfate concentrations was observed repeatedly after each of five consecutive landslides on the La Clapière slope, thus attesting to the mechanical deformations are at the origin of this concentration change. Significant changes in the water chemistry are produced even from slow (mm/year) and low magnitude deformations of the geological settings.

Pyrite nuclei in open fractures were found to be coated by iron oxides. This suggests that the increase of dissolved sulfate relates to oxidative dissolution of Pyrite. Speciation calculations of Pyrite versus Gypsum confirmed that observed changes in the sulfate concentrations is predominantly provided from Pyrite. Calculated amounts of dissolved minerals in the springs water was obtained through inverse modelling of the major ion water analysis data. It is shown that the concentration ratio of calculated dissolved Pyrite versus calculated dissolved gneiss rock allows us to unambiguously
\end{abstract}

Correspondence to: S. Binet (stephane.binet@univ-orleans.fr) distinguish water from stable and unstable areas. This result opens an interesting perspective for the follow-up of sliding or friction dynamic in landslides or in (a) seismic faults.

\section{Introduction}

The water in fractured rock is one of the major triggering factors that influence the rock stability (Keefer et al., 1987). The water saturation conditions determines the interstitial pressure. Changing interstitial pressure may cause fracture growth and landslides which, in turn, affect the infiltration conditions and the groundwater pathways (Guglielmi et al., 2005) and this potentially impacts the water transfer time and the water saturation conditions (Bonzanigo et al., 2001). During a deformation event, the combination of all these effects may affect, in turn, the interstitial pressure and, thus, the overall stability of the rock masses (Forlati et al., 2001). Thus, a good hydrogeological knowledge is necessary to realize an accurate stability evaluation.

Because of the variability of crack openings, the transfer time of individual water molecules differ strongly in these fractured areas, dependent on the chosen flow path. The heterogeneity of the fractured rocks and their perpetual displacements makes it difficult to monitor groundwater through installations of automated devices. Such devices are readily broken and/or lost when installed in unstable areas. To overcome these difficulties, hydrogeologists had to transfer

Published by Copernicus Publications on behalf of the European Geosciences Union. 
specific hydrogeochemical methods from karstic hydrology (Mudry, 1990) to the unstable fractured areas (Vengeon, 1998; Guglielmi et al., 2000; Tullen, 2002) in the aim of characterizing the groundwater flows. The results highlight - pore water pressure triggers the gravitational deformation - induce a motion of the entire rocky slope - a propagation of discontinuities in the rock material (Barla and Chiriotti, 1996; Agliardi et al., 2001). It can generate additional cracks (Scavia, 1995) leading to a porosity and permeability changes creating a new water pressure distribution (Binet et al., 2007c).

Thus, in theory this hydro-mechanical deformation phenomenon may generate additional reactive surface areas which, in turn, can change the chemical weathering rate and the groundwater chemistry. The aim of the present study is to characterise the chemical changes of major ions of water flowing through gravitational active faults compared to inactive ones in a similar geological context. The changes in the water chemistry obtained within the framework of a long survey, indicates that sliding velocity and chemical composition are closely related. Unstable areas could be unambiguously determined by an original approach, which is based on the determination of the potentially dissolving minerals in spring water. This result opens interesting perspectives for monitoring the deformations and can provide a tool for the an eventual fracture growth monitoring.

\section{Material and methods}

\subsection{Study sites}

"Tinée" (Southern Alps, France) and "Orco" (Rosone slope in the Eastern Alps, Italy) are two Alpine valleys composed of gneiss rocks (Fig. 1). These valleys are characterised by continuous landslide movements (Barla and Chiriotti, 1996; Casson et al., 2003), which shaped the landscape from the post-glacial period (Julian and Anthony, 1996). The past and actual landslides in these valleys may mobilize several million cubic metres of rock. Due to the inherent risk, both Italian and French government authorities (Follacci, 1987; Amatruda et al., 2004) monitor the actual active slope deformations. In Fig. 1, the locations and velocities of the actual movements are symbolized by grey surfaces. In these areas, different kinds of deformation were described by Julian and Anthony (1996). Toppling, in the higher part of the slopes (1500-2500 m above-sea-level), where cracks and trenches move typically some mm per year (Fig. 1d). Downhills, velocities of more than one metre per year were recorded in 1997 and 2001 by the French authorities, in the "La Clapière" landslide and about 1 to $10 \mathrm{~cm}$ in 2001 in the "Rosone" landslide recorded by Italian authorities. The deformation velocities are recorded using a distancemeter - tachometer, the detection limits are under $1 \mathrm{~cm} / \mathrm{an}$. More detailed methodologies of the ground deformation monitorings used in this paper are described in Follacci (1987) and Amatruda et al. (2004).

The flow and geological conditions are as follows: In the Tinée valley, the rainwater infiltrates through the fractured gneiss rocks at the top of the hillslope around 1500$2000 \mathrm{~m}$ above sea level (ma.s.l.) and moves to the valley (1000 m a.s.l.) (Cappa et al., 2004; Binet et al., 2007b). Water flows through the cracks, until it reaches $100 \mathrm{~m}$ under the ground surface where it arrives at the saturated zone where it increases the pore pressure and, thus, participates in the landslide triggering (Cappa et al., 2004). Local high permeable Triassic and Jurassic deposits are pinched in gneiss rock (see $T$ in the Fig. 1), for example under the foot of the La Clapière landslide (Gunzburger and Laumonier, 2002). Such deposits were observed in the Tinée valley close to the S15 springs and at the top of the Mounier mount (Fig. 1).

In the Orco valley, water flows through a $10 \mathrm{~m}$ deep subsurface aquifer (developed in the weathered gneiss rocks and decompressed cracks of the slope. The groundwater recharge occurs locally in the upper part of the slope by infiltration at about $2500-1900 \mathrm{~m}$ a.s.l. In this valley, the groundwater will not be in contact with gypsum-rich Triassic formations. Instead, some of the areas are covered by glacial deposits which may be the principal aquifers for specific sources. The main outflow occurs downhill from the Rosone unstable area (around $1000 \mathrm{~m}$ a.s.l) (Binet et al., 2007a).

\subsection{Sampling and analysis of the Alpine crystalline rocks}

Our own field trips (Binet et al., 2007a, b), combined with previous investigations (Mazeran and Féraud, 1974; Féraud et al., 1975; Gunzburger and Laumonier, 2002) lead to the establishment of the list of the major rocks and associated minerals determined in the investigated areas (Table 1).

During the field trips, the cracks retained particular attention, especially when sliding patterns of rock were observed inside these fractures. Figure $4 \mathrm{a}$ represents an example of fractures (located by a cross in Fig. 1c) dipping West in the slope direction reactivated by gravity deformation. The fractures, dipping East (i.e. perpendicular to the sliding direction), are non-reactivate (Guglielmi et al., 2005). Four Samples from these reactivated and non-reactivated cracks were carefully recovered to preserve the surfaces exposed to air and water. $20 \mathrm{~mm}$-sized particles were analysed with a Jeol 35 CF Scanning electronic microscope. Spot chemical analysis were obtained froma X-ray Fondis microprobe analyser. 

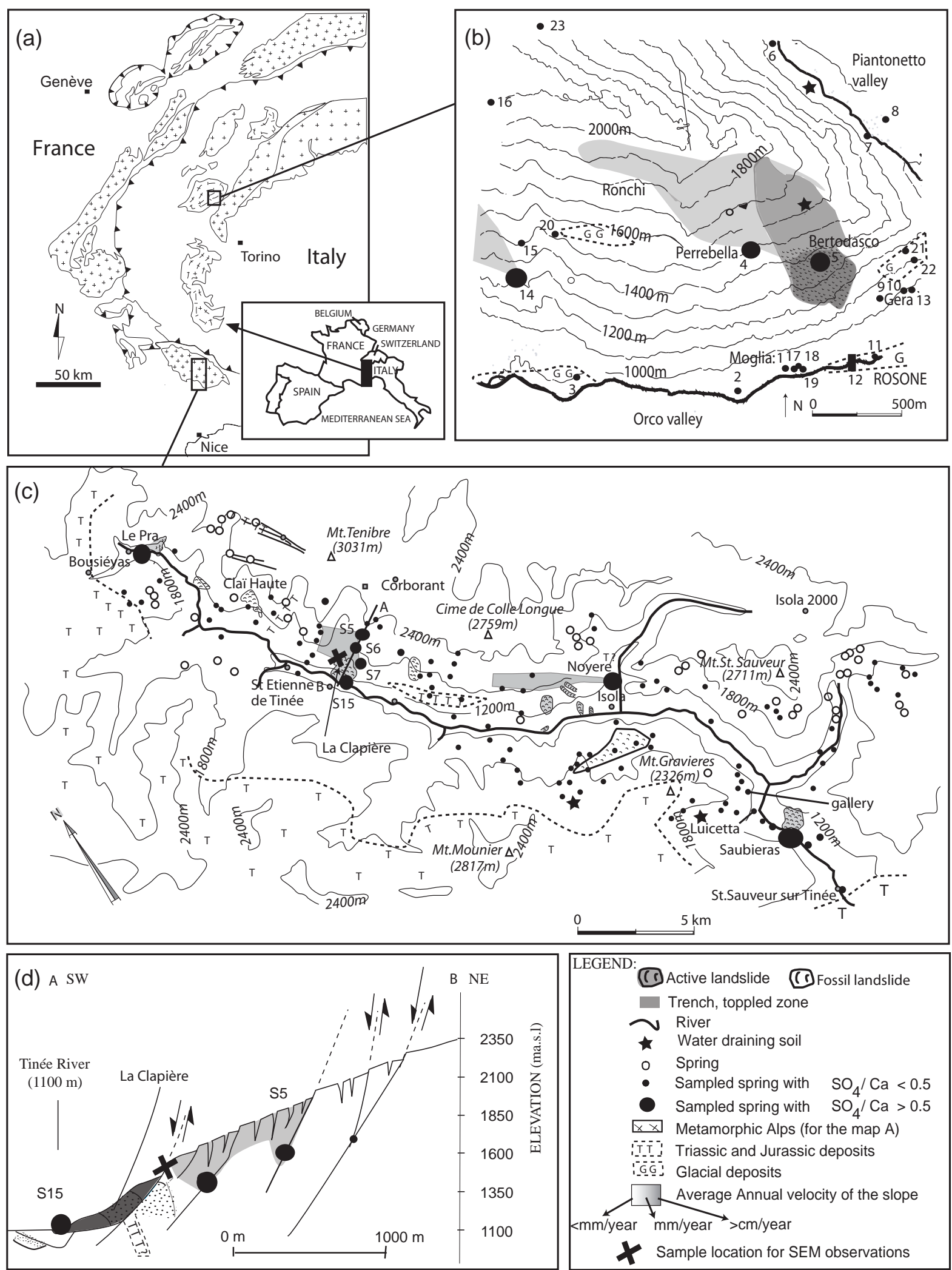

Fig. 1. (a) Structural map of the Alps with detailed map of (b) the Rosone slope (Grande Paradiso) and (c) the Tinée Valley (Mercantour massif) (d) schematic geological cross-section through the "La Clapière" landslide and localization of the monitored springs. 
Table 1. Main and secondary minerals observed in the Orco and Tinée valleys. Molar percentage and chemical equations of the dissolution in a gneiss rock media are assessed for the La Clapière slope by Guglielmi et al. (2000). Log (K) values come from wateq4f database (Parkust and Appelo, 2004).

\begin{tabular}{|c|c|c|c|}
\hline Minerals & $\%$ molar & $\log (\mathrm{K})$ & Dissociation equations \\
\hline Quartz & 66 & -3.98 & $\mathrm{SiO}_{2}+2 \mathrm{H}_{2} \mathrm{O} \Leftrightarrow \mathrm{H}_{4} \mathrm{SiO}_{4}$ \\
\hline Kmica & 4.1 & 11.63 & $\mathrm{KAl}_{3} \mathrm{Si}_{3} \mathrm{O}_{10}(\mathrm{OH}) 2+9 \mathrm{H}_{2} \mathrm{O}+\mathrm{H}^{+} \Leftrightarrow \mathrm{K}^{+}+3 \mathrm{H}_{4} \mathrm{SiO}_{4}+3 \mathrm{Al}(\mathrm{OH})_{3}$ \\
\hline Phlogopite & 3.0 & -35.19 & $\mathrm{KMg}_{3} \mathrm{AlSi}_{3} \mathrm{O}_{10}(\mathrm{OH})_{2}+7 \mathrm{H}^{+}+3 \mathrm{H}_{2} \mathrm{O} \Leftrightarrow \mathrm{K}^{+}+3 \mathrm{Mg}^{+2}+3 \mathrm{H}_{4} \mathrm{SiO}_{4}+\mathrm{Al}(\mathrm{OH})_{3}$ \\
\hline \multicolumn{4}{|c|}{ Plagioclase solid solution between: } \\
\hline Albite & I & 4.6 & $\mathrm{NaAlSi}_{3} \mathrm{O}_{8}+\mathrm{H}^{+}+7 \mathrm{H}_{2} \mathrm{O} \Leftrightarrow \mathrm{Na}^{+}+3 \mathrm{H}_{4} \mathrm{SiO}_{4}+\mathrm{Al}(\mathrm{OH})_{3}$ \\
\hline Anorthite & l & -9.21 & $\mathrm{CaAl}_{2} \mathrm{Si}_{2} \mathrm{O}_{8}+2 \mathrm{H}^{+}+6 \mathrm{H}_{2} \mathrm{O} \Leftrightarrow \mathrm{Ca}^{+2}+2 \mathrm{H}_{4} \mathrm{SiO}_{4}+2 \mathrm{Al}(\mathrm{OH})_{3}$ \\
\hline Plagioclase An 70 & 8.0 & -9 & $\mathrm{Na}_{0.3} \mathrm{Ca}_{0.7} \mathrm{Al}_{1.7} \mathrm{Si}_{2.3} \mathrm{O}_{8}+6.3 \mathrm{H}_{2} \mathrm{O}+1.7 \mathrm{H}^{+} \Leftrightarrow .3 \mathrm{Na}^{+}+.7 \mathrm{Ca}^{+2}+1.7 \mathrm{Al}(\mathrm{OH})_{3}+2.3 \mathrm{H}_{4} \mathrm{SiO}_{4}$ \\
\hline \multicolumn{4}{|l|}{ Secondary minerals } \\
\hline Pyrite & I & -18.48 & $\mathrm{Fe} \mathrm{S}_{2}+3.75 \mathrm{O}_{2}+3.5 \mathrm{H}_{2} \mathrm{O} \Leftrightarrow 4 \mathrm{H}^{+}+\mathrm{Fe}(\mathrm{OH})_{3}+2 \mathrm{SO}_{4}^{2-}$ \\
\hline Fe oxides & l & 4.89 & $\mathrm{Fe}(\mathrm{OH})_{3}+3 \mathrm{H}^{+} \Leftrightarrow \mathrm{Fe}^{+3}+3 \mathrm{H}_{2} \mathrm{O}$ \\
\hline Gibbsite & / & 8.11 & $\mathrm{Al}(\mathrm{OH})_{3}+3 \mathrm{H}^{+} \Leftrightarrow \mathrm{Al}^{+3}+3 \mathrm{H}_{2} \mathrm{O}$ \\
\hline Gypsum & / & -4.58 & $\mathrm{Ca} \mathrm{SO}_{4} 2 \mathrm{H}_{2} \mathrm{O} \Leftrightarrow \mathrm{Ca}^{2+}+\mathrm{SO}_{4}^{2-}+2 \mathrm{H}_{2} \mathrm{O}$ \\
\hline Halite & l & 1.58 & $\mathrm{NaCl} \Leftrightarrow \mathrm{Na}^{+}+\mathrm{Cl}^{-}$ \\
\hline Dolomite & / & -16.54 & $\mathrm{CaMg}\left(\mathrm{CO}_{3}\right)_{2} \Leftrightarrow \mathrm{Ca}^{+2}+\mathrm{Mg}^{+2}+2 \mathrm{CO}_{3}^{-2}$ \\
\hline Calcite & I & -8.48 & $\mathrm{Ca} \mathrm{CO}_{3} \Leftrightarrow \mathrm{Ca}^{2+}+\mathrm{CO}_{3}^{2-}$ \\
\hline
\end{tabular}

\subsection{Sampling and analysis of the Alpine crystalline basement groundwater}

\subsubsection{Spatial variability of groundwater chemistry}

The water composition of a large number of the Tinée and the Orco valley springs was determined during the low waterlevel periods (recession stage).In the Tinée valley, 92 springs were analyzed during an intensive campaign in August 2003 (Fig. 1c). On the Orco valley, 22 springs were analyzed in June 2004 (Fig. 1b).

Each sample was classified depending on the geological environment of catchment (soil, gneiss rock, glacial or Triassic deposits in Fig. 1 based on geological map described in Faure-Muret, 1955) and on the stability of the corresponding formations (are some rock deformations known in the catchment or not?). The stable/unstable classification was based on geomorphological observations and on prior slope stability studies performed in these two valleys (Forlati et al., 2001; Julian and Anthony, 1996). The "La Clapière" region and the Rosone slope are known to be a very unstable area. In all these sites, the water flows from soil to the gneiss rock but in different environments of slope stabilities: Unstable for S15 and S5 La Clapière (Tinée) and Bertodosca Rosone (Orco) springs, and stable for Luicetta (Tinée) and Moglia (Orco) springs.

Corresponding sulfate and calcium data of all springs are given in Fig. 3, and Table 2 gives the complete water chemical analysis for the main springs draining through gneiss rock of the two valleys.

\subsubsection{Temporal variability of groundwater chemistry}

Previous studies pointed to the S15 spring, situated downstream of the landslide, drains the water flowing through this unstable area (Guglielmi et al., 2000, 2002). The water composition and the temporal variability of this spring were consequently studied in the framework of a nine year survey (1995 to 2004). Table 3 presents the complete water chemical analysis of the S15 spring situated at the foot of the landslide for ten dates that characterise the surrounding data, and Fig. 4 represents the sulfate concentrations of the whole survey.

The periods of freshwater intrusion into the S15 aquifer downstream needs to be identified. The presence of groundwater Nitrate levels above the detection limit ( $>0.001 \mathrm{mmol} / \mathrm{L}$ ) correlated to meteorological events (snow melting and rainfall), whereas in the recession stages (low water period) showed that nitrate contributions decreased below the detection limit. The recession stages where consequently associated with periods of null nitrate concentration. The sulfate measurements realized during the low water period are plotted in Fig. 4 with a square symbol. Such exhaustive long-time surveys are not available for the other sites.

\subsubsection{Analytic protocol}

Aqueous $\mathrm{K}, \mathrm{Na}, \mathrm{Ca}$ and $\mathrm{Mg}$ concentrations were measured after acidification on a Perkin Elmer A Analyst 100 atomic absorption spectrometer (AAS); $\mathrm{SO}_{4}^{-2}, \mathrm{Cl}^{-}$and $\mathrm{NO}_{3}^{-}$were obtained from High Pressure Ionic Chromatography (HPLC, 
Table 2. Spatial variability of water quality recorded on the six major springs from the two studied valleys. S5 refers to the spring of the La Clapière (Tinée) site. Calculated values of the saturation index (SI) and inversed values of the amount of dissolved minerals (positive values means dissolution, negative values means precipitation, inversed $\mathrm{O}_{2}$ values exceed the saturation limit, this means that the system is open for oxygen).

\begin{tabular}{|c|c|c|c|c|c|c|c|c|c|c|c|c|c|c|c|}
\hline \multirow{2}{*}{$\begin{array}{l}\text { Spring } \\
\text { Sample ID }\end{array}$} & & \multicolumn{6}{|c|}{ S5 } & \multicolumn{2}{|c|}{ Luicetta } & \multicolumn{2}{|c|}{ Gallery } & \multirow{2}{*}{$\begin{array}{c}\text { Bertod. } \\
\mathrm{B}(1)\end{array}$} & \multirow{2}{*}{$\begin{array}{c}\text { Moglia } \\
\text { M(1) }\end{array}$} & \multirow{2}{*}{$\begin{array}{c}\text { Gera } \\
\mathrm{Ge}(1)\end{array}$} & \multirow{2}{*}{$\begin{array}{c}\text { Soil } \\
\text { S }\end{array}$} \\
\hline & & $\mathrm{S} 5(1)$ & $\mathrm{S} 5(2)$ & $\mathrm{S} 5(3)$ & S5(4) & $\mathrm{S} 5(5)$ & $\mathrm{S} 5(6)$ & $\mathrm{L}(1)$ & $\mathrm{L}(2)$ & $\mathrm{G}(1)$ & $\mathrm{G}(2)$ & & & & \\
\hline Sampling date & & 12.98 & 04.99 & 09.00 & 06.02 & 08.03 & 04.04 & 05.03 & 07.04 & 03.03 & 04.04 & 06.04 & 06.04 & 06.04 & 03.03 \\
\hline Aquifer type & & \multicolumn{6}{|c|}{ Toppling zone } & \multicolumn{2}{|c|}{ Stable } & \multicolumn{2}{|c|}{ Stable } & Unstable & Stable & Stable & Soil \\
\hline Location & & \multicolumn{6}{|c|}{ Tinée valley } & \multicolumn{2}{|c|}{ Tinée valley } & \multicolumn{2}{|c|}{ Tinée valley } & \multicolumn{3}{|c|}{ Rosone } & \\
\hline \multicolumn{16}{|l|}{ Measured values } \\
\hline Velocity & $(\mathrm{mm} / \mathrm{mo})$ & $<1$ & $<1$ & $<1$ & $<1$ & $<1$ & $<1$ & I & 1 & 1 & 1 & 10 & 1 & 1 & 1 \\
\hline Rain & $(\mathrm{mm} / \mathrm{mo})$ & 34 & 117 & 97 & 57 & 40 & 72 & 0 & 0 & 0 & 72 & 0 & 0 & 0 & / \\
\hline Yield & $(1 / s)$ & / & 0.10 & 0.10 & 0.10 & 0.1 & 0.15 & 4.75 & 4.5 & 0.05 & 0.01 & 2.0 & 5 & 0.7 & / \\
\hline Conductivity & $(\mu \mathrm{S} / \mathrm{cm})$ & 199 & 136 & 229 & 160 & 189 & 158 & 152 & 163 & 400 & 333 & 28 & 60 & 84 & 28 \\
\hline Temp & $\left({ }^{\circ} \mathrm{C}\right)$ & 8.2 & 8.0 & 12.0 & 10.0 & 11.3 & 7.7 & 9.9 & 11.9 & 10.1 & 11.3 & 6.1 & 8.1 & 7 & 6.40 \\
\hline $\mathrm{pH}$ & & 7.5 & 7.1 & 7.9 & 8.0 & 7.5 & 6.9 & 8.1 & 8.0 & 7.9 & 8.2 & 7.7 & 8.0 & 8.2 & 5.50 \\
\hline $\mathrm{Eh}$ & $(\mathrm{mV} / \mathrm{H} 2)$ & & & & 460 & & 455 & & 460 & & & & & & 625 \\
\hline $\mathrm{HCO}_{3}^{-}$ & $(\mathrm{mmol} / \mathrm{L})$ & 1.20 & 0.90 & 0.80 & 0.80 & 0.84 & 0.72 & 1.1 & 1.08 & 2.55 & 2.29 & 0.20 & 0.42 & 0.44 & 0.10 \\
\hline $\mathrm{Cl}^{-}$ & $(\mathrm{mmol} / \mathrm{L})$ & 0.02 & 0.02 & 0.06 & 0.02 & 0.08 & 0.03 & 0.03 & 0.04 & 0.05 & 0.06 & 0.02 & 0.02 & 0.15 & 0.02 \\
\hline $\mathrm{SO}_{4}^{2-}$ & $(\mathrm{mmol} / \mathrm{L})$ & 0.48 & 0.28 & 0.53 & 0.50 & 0.51 & 0.38 & 0.19 & 0.17 & 0.79 & 0.59 & 0.05 & 0.06 & 0.07 & 0.03 \\
\hline $\mathrm{Ca}^{2+}$ & $(\mathrm{mmol} / \mathrm{L})$ & 0.70 & 0.51 & 0.56 & 0.70 & 0.78 & 0.47 & 0.65 & 0.62 & 1.85 & 1.50 & 0.06 & 0.18 & 0.21 & 0.03 \\
\hline $\mathrm{Mg}^{2+}$ & $(\mathrm{mmol} / \mathrm{L})$ & 0.18 & 0.12 & 0.19 & 0.12 & 0.13 & 0.17 & 0.09 & 0.09 & 0.12 & 0.12 & 0.02 & 0.03 & 0.05 & 0.02 \\
\hline $\mathrm{Na}^{+}$ & $(\mathrm{mmol} / \mathrm{L})$ & 0.38 & 0.21 & 0.22 & 0.20 & 0.29 & 0.26 & 0.15 & 0.11 & 0.22 & 0.2 & 0.07 & 0.08 & 0.23 & 0.02 \\
\hline $\mathrm{K}^{+}$ & $(\mathrm{mmol} / \mathrm{L})$ & 0.04 & 0.04 & 0.07 & 0.04 & 0.04 & 0.06 & 0.02 & 0.03 & 0.03 & 0.03 & 0.04 & 0.05 & 0.03 & 0.02 \\
\hline $\mathrm{NO}_{3}^{-}$ & $(\mathrm{mmol} / \mathrm{L})$ & 0.006 & 0.019 & 0.016 & 0.006 & 0.006 & 0.024 & 0.006 & 0.006 & 0.006 & 0.015 & 0.035 & 0.031 & 0.019 & 0.000 \\
\hline $\mathrm{SO}_{4} / \mathrm{Ca}$ & & 0.69 & 0.55 & 0.94 & 0.71 & 0.66 & 0.81 & 0.29 & 0.28 & 0.43 & 0.39 & 0.76 & 0.33 & 0.32 & 0.83 \\
\hline Electrical balance $\%$ & & 0.2 & -0.8 & 3.4 & -1.6 & -4.9 & -2.5 & -4.6 & -3.3 & 0.0 & 0.6 & 3.3 & 0.8 & -5.1 & 8.57 \\
\hline \multicolumn{16}{|l|}{ Calculated values } \\
\hline $\mathrm{Fe}$ & $(\mathrm{mmol} / \mathrm{L})$ & $3 \mathrm{E}-06$ & $4 \mathrm{E}-06$ & $4 \mathrm{E}-06$ & $3 \mathrm{E}-06$ & $3 \mathrm{E}-06$ & $3 E-06$ & $3 \mathrm{E}-05$ & $4 \mathrm{E}-06$ & $3 \mathrm{E}-06$ & $3 \mathrm{E}-06$ & $1 \mathrm{E}-06$ & $2 \mathrm{E}-06$ & $2 \mathrm{E}-06$ & $4 \mathrm{E}-4$ \\
\hline $\mathrm{PCO}_{2}$ & $(\log (\operatorname{atm}))$ & -2.7 & -2.4 & -3.2 & -3.4 & -2.8 & -2.3 & -3.3 & -3.3 & -2.8 & -3.2 & -3.5 & -3.3 & -3.5 & -1.80 \\
\hline $\mathrm{Eh}$ & $(\mathrm{mV} / \mathrm{H} 2)$ & 551 & 597 & 460 & 460 & 462 & 457 & 417 & 482 & 542 & 417 & 435 & 478 & 441 & 630 \\
\hline SI pyrite & & -181 & -190 & -172 & -169 & -191 & -198 & -164 & -192 & -179 & -177 & -192 & -176 & -172 & -220 \\
\hline SI gypsum & & -2.1 & -2.5 & -2.2 & -2.1 & -2.1 & -2.4 & -2.5 & -2.6 & -1.6 & -1.8 & -4.0 & -3.5 & -3.4 & -4.39 \\
\hline SI calcite & & -0.9 & -1.5 & -0.7 & -0.5 & -0.9 & -1.8 & -0.3 & -0.4 & 0.3 & 0.5 & -1.9 & -1.6 & -1.2 & -5.60 \\
\hline \multicolumn{16}{|l|}{ Inversed values } \\
\hline Pyrite & $(\mathrm{mmol} / \mathrm{L})$ & 0.25 & 0.12 & 0.25 & 0.24 & 0.24 & 0.18 & 0.08 & 0.08 & 0.38 & 0.29 & 0.013 & 0.01 & 0.02 & \\
\hline Plagioclase & $(\mathrm{mmol} / \mathrm{L})$ & 1.01 & 0.63 & 0.69 & 0.74 & 0.6 & 0.67 & 0.6 & 0.61 & 2.7 & 2.25 & 0.95 & 0.18 & 0.52 & ฮే \\
\hline Phlogopite + Kmica & $(\mathrm{mmol} / \mathrm{L})$ & 0.04 & 0.02 & 0.06 & 0.03 & 0.03 & 0.04 & 0.02 & 0.02 & 0.03 & 0.03 & 0.01 & 0.01 & 0.01 & 鸪 \\
\hline Calcite & $(\mathrm{mmol} / \mathrm{L})$ & I & / & 1 & 1 & I & I & 1 & I & -0.7 & -1.05 & / & / & / & $\frac{\sqrt{0}}{5}$ \\
\hline Gibbsite & $(\mathrm{mmol} / \mathrm{L})$ & -1.76 & -1.10 & -1.20 & -1.52 & -1.5 & -1.2 & -1.18 & -1.2 & -5.3 & -5.26 & -0.12 & -0.32 & -0.89 & 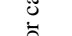 \\
\hline $\mathrm{Fe}(\mathrm{OH})_{3(\mathrm{a})}$ & $(\mathrm{mmol} / \mathrm{L})$ & -0.25 & -0.12 & -0.20 & -0.23 & -0.2 & -0.19 & -0.08 & -0.1 & -0.4 & -0.29 & -0.01 & 0 & -0.02 & $\stackrel{0}{*}$ \\
\hline $\mathrm{O}_{2(\mathrm{~g})}$ & $(\mathrm{mmol} / \mathrm{L})$ & 0.97 & 0.46 & 0.78 & 0.88 & 0.88 & 0.72 & 0.31 & 0.3 & 1.43 & 1.07 & 0.03 & 0.05 & 0.05 & 莺 \\
\hline $\mathrm{CO}_{2(\mathrm{~g})}$ & $(\mathrm{mmol} / \mathrm{L})$ & 0 & 0 & 0 & 0 & 0 & 0 & 0 & 0 & 0 & 0 & 0 & 0 & 0 & $\Xi$ \\
\hline Gneiss $=\Sigma$ Plag. + Phlo & & 1.05 & 0.65 & 0.75 & 0.77 & 0.63 & 0.71 & 0.62 & 0.63 & 2.73 & 2.28 & 0.96 & 0.19 & 0.53 & $\bar{\Xi}$ \\
\hline Py/Gneiss & $(\mathrm{mmol} / \mathrm{L})$ & 0.24 & 0.18 & 0.33 & 0.31 & 0.38 & 0.254 & 0.129 & 0.13 & 0.14 & 0.13 & 0.01354 & 0.0526 & 0.038 & \\
\hline
\end{tabular}

Dionex DX 100) measurements, the alkalinity $\left(\mathrm{HCO}_{3}^{-}\right.$ concentration) was obtained using standard titrimetric methods. Detection limits are 0.005 and $0.002 \mathrm{mmol} / \mathrm{L}$ for AAS and HPLC tools and the precisions are $5 \% \pm 1 \%$ for AAS, HPLC and alkalinity.

\section{Results: field measurements of water quality and correlation with unstabilities}

\subsection{Analysis of in situ gneiss matrix and fractures walls}

Gneiss rock is the dominant rock found in both valleys. The mineralogical composition, of Tinée gneiss rock was previously determined by Mazeran and Féraud (1974) and Féraud (1975): 66\% quartz, 3\% Biotite, 4\% Kmica,
8\% Plagioclase solid solution with $70 \%$ of Anorthite and $30 \%$ of Albite. The global mineralogical composition of the Rosone gneiss rock described in Amatruda et al. (2004) appears to be similar to the Tinée gneiss rock.

Inside cracks, secondary minerals such as pyrite, calcite and amorphous Ferric oxides were found beneath the essential primary minerals forming the gneiss rock found everywhere else.

The microprobe analysis confirmed the presence of $\mathrm{S}$ in active fractures, and the presence of $\mathrm{Fe}$ and $\mathrm{O}$ beneath the usual $\mathrm{Si}, \mathrm{Al}, \mathrm{O}, \mathrm{Na}, \mathrm{Mg}, \mathrm{K}, \mathrm{Ca}$ gneiss rock constituting elements composition. Image analysis revealed that the corresponding sulfur (Fig. 2b) and Fe oxide minerals (Fig. 2b), of active and inactive fractures, are localized. 
(a) Cross section

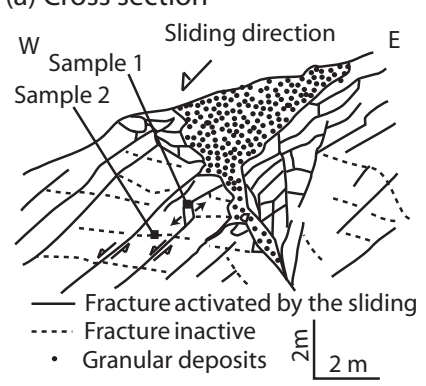

(b) sample 1

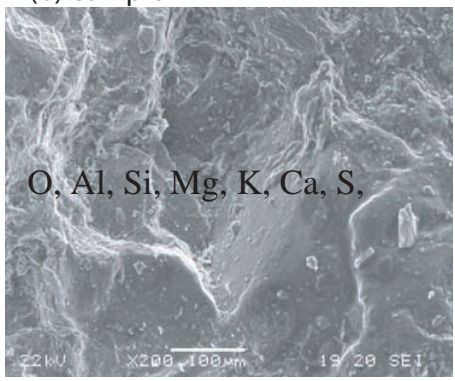

(c) sample 2

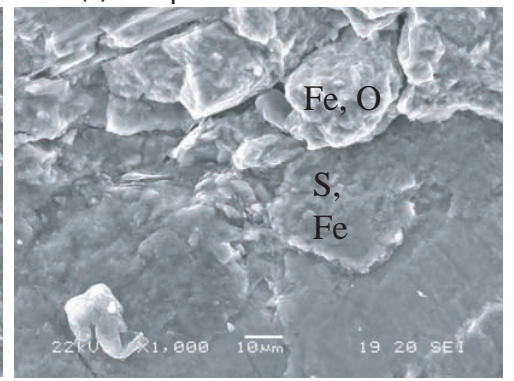

Fig. 2. Localization and observations of fracture walls: (a) Localization of fractures in a cross-section with sliding displacements along fracture dipping towards West (b) electronic microscope and micro-probe results in an active (dipping west, sample 1) fracture and (c) in an inactive (dipping Est, sample 2) fracture covered with a thin ferric layer.

\subsection{Water chemistry composition}

\subsubsection{Dependent on geological formations}

The water (four samples) from the soil has a 580$650 \mathrm{mV} / \mathrm{H} 2$ redox value and the bicarbonate concentration is $0.1 \mathrm{mmol} / \mathrm{L} \pm 0,01$. The calculated $\log$ of the $\mathrm{CO}_{2}$ pressures ranges from -1.7 to -1.9 . Average values are presented in Table 2.

The water from gneiss rock (quartz, biotite, Kmica, plagioclase and pyrite) is characterised by low $\mathrm{Mg}^{2+}$ concentrations, $(0.02$ to $0.18 \mathrm{mmol} / \mathrm{L})$ low electric conductivity $(<500 \mu \mathrm{S} / \mathrm{cm})$, and strongly variable $\mathrm{SO}_{4}^{2-}$ concentrations ( 0.03 to $0.79 \mathrm{mmol} / \mathrm{L}$, Table 2 ).

The water collected from downstream Triassic-Jurassic formations is characterised by high $\mathrm{SO}_{4}^{2-}$ concentration ( $>1 \mathrm{mmol} / \mathrm{L}$, "Mont Mounier" downhill springs and S15, Fig. 3a insert), high electrical conductivities ( $>500 \mu$ Siemens/cm) and high $\mathrm{Mg}^{2+}$ concentrations $\left(>1.5 \mathrm{mmol} / \mathrm{L}\right.$ ). This suggests the dissolution of $\mathrm{Ca}-\mathrm{Mg}-\mathrm{SO}_{4}$ gypsum dolomite Triassic formations (Fig. 1). This applied, for example, to the S15 spring (Table 3). This variability was already described in a previous study (Guglielmi et al., 2000; Binet et al., 2007b). Such water interacted supposedly with limestones, gypsum and pyrite.

Figure 3 presents the $\mathrm{SO}_{4}$ versus Ca concentration ratios of the Tinée (Fig. 3a) and the Rosone slope (Fig. 3b) springs. The data presented are dependent on geological and geomorphological conditions. In both valleys, the water from gneiss rock type are characterised by a constant $\mathrm{SO}_{4} / \mathrm{Ca}$ ratio of $0.2-$ 0.3 . Triassic rock presents a ratio of 1 , but with an offset of around $0.8 \mathrm{mmol} / \mathrm{L}$ of calcium for $0 \mathrm{mmol} / \mathrm{L}$ of sulfate. Water flowing through Triassic rocks is, thus, characterised by a ratio of 1 with high concentrations in calcium and sulfate. A ratio smaller than 0.1 corresponds to the glacial deposit types, which was only observed in the Rosone slope.

\subsubsection{Dependent on stable/unstable zones}

In the Tinée valley, the "La Clapière" (S15, S5, S6), "Noyere", "Pra" and "Saubieras" springs drain from currently unstable areas (displacements of $>1 \mathrm{~mm} /$ year, gray shaded in Fig. 1). The three Rosone slope springs, 14, Bertodasco 5 and Perrebella 4, are known to be located in the moving zone (Fig. 1b, (Amatruda et al., 2004)). The $\mathrm{SO}_{4} / \mathrm{Ca}$ concentration ratios of all these waters from unstable slopes are higher than 0.5 (big circles in Fig. 1), contrary to all water from stable zones (Fig. 3). This single parameter allows the discrimination of moving versus non-moving zones. This means that the ground movements correlates with excess sulfate concentrations in the water compared to calcium.

\subsubsection{Dependent on landslide motion}

The $\mathrm{S} 15$ spring is characterised by a particularly high $\mathrm{SO}_{4}$ concentration during the recession stage. The long observation period of the S15 spring (Fig. 4) shows that the sulfate changes with time and relates to the landslide acceleration (strong accelerations are grey shaded in Fig. 4). Thus, in 4/1996, a $8.5 \mathrm{mmol} / \mathrm{L}$ concentration (see S15(0) in Table 3) after an high acceleration is observed. It then decreases to 7.9 in the low movement period until 12/1996. Similarly in 1999 , after a relatively long low movement period (concentration at $6.2 \mathrm{mmol} / \mathrm{L}$ in S15 (1 and 2) in May 1999), the concentrations increased to 7 in December 1999. Two short increases of the concentrations from 6.8 to 8.8 and to 6 to $6.5 \mathrm{mmol} / \mathrm{L}$ is also observed in 2000 . The $02 / 2001$ acceleration of the landslide is correlated with 7.4 sulfate concentration (S15(4)). Then an overall decrease from 2002 (see S15 (7, 8 and 9)). These movements correlate qualitatively and positively to the landslide acceleration. Note that the S15(5) analysis is an example of a no null nitrate value. The water is influenced by fresh water intrusion. 
Table 3. Temporal variability of water quality recorded on the S15 springs draining the la Clapière landslide. Calculated values of the saturation index (SI) and inversed values of the amount of dissolved minerals (positive values means dissolution, negative values means precipitation, inversed $\mathrm{O}_{2}$ values exceed the saturation limit, this means that the system is open for oxygen).

\begin{tabular}{|c|c|c|c|c|c|c|c|c|c|c|c|}
\hline \multirow{2}{*}{$\begin{array}{l}\text { Spring } \\
\text { Sample ID }\end{array}$} & & \multicolumn{10}{|c|}{ S15 } \\
\hline & & $\mathrm{S} 15(0)$ & $\mathrm{S} 15(1)$ & $\mathrm{S} 15(2)$ & $\mathrm{S} 15(3)$ & $\mathrm{S} 15(4)$ & $\mathrm{S} 15(5)$ & $\mathrm{S} 15(6)$ & $\mathrm{S} 15(7)$ & S15(8) & $\mathrm{S} 15(9)$ \\
\hline Sampling date & & 04.96 & 12.98 & 05.99 & 07.00 & 02.01 & 04.01 & 11.01 & 06.02 & 09.03 & 04.04 \\
\hline Aquifer type & & \multicolumn{10}{|c|}{ Moving zone: La Clapière landslide } \\
\hline \multicolumn{12}{|l|}{ Measured values } \\
\hline Velocity & $(\mathrm{mm} / \mathrm{mo})$ & 1500 & 36 & 23 & 66 & 1437 & 1241 & 35 & 8 & 22 & 21 \\
\hline Conductivity & $(\mu \mathrm{S} / \mathrm{cm})$ & 1496 & 1440 & 1404 & 1331 & 1518 & 902 & 1523 & 1508 & 1519 & 1198 \\
\hline Temp & $\left({ }^{\circ} \mathrm{C}\right)$ & 11.3 & 8.2 & 16.6 & 20.0 & 9.7 & 9.4 & 9.6 & 12.1 & 12.4 & 9.7 \\
\hline $\mathrm{pH}$ & & 7.2 & 8.0 & 7.9 & 74 & 81 & 7.5 & 8.0 & 7.7 & 7.9 & 8.2 \\
\hline $\mathrm{Eh}$ & $(\mathrm{mV} / \mathrm{H} 2)$ & & & & & & & & 515 & & 453 \\
\hline $\mathrm{HCO}_{3}^{-}$ & $(\mathrm{mmol} / \mathrm{L})$ & 2.88 & 3.64 & 3.00 & 1.50 & 1.72 & 1.25 & 3.68 & 3.72 & 3.68 & 2.00 \\
\hline $\mathrm{Cl}^{-}$ & $(\mathrm{mmol} / \mathrm{L})$ & 0.09 & 0.17 & 0.15 & 0.13 & 0.13 & 0.20 & 0.12 & 0.18 & 0.10 & 0.13 \\
\hline $\mathrm{Na}^{+}$ & $(\mathrm{mmol} / \mathrm{L})$ & 0.72 & 0.99 & 0.70 & 0.86 & 0.81 & 0.71 & 0.84 & 0.84 & 0.74 & 0.94 \\
\hline $\mathrm{K}^{+}$ & $(\mathrm{mmol} / \mathrm{L})$ & 0.15 & 0.15 & 0.15 & 0.19 & 0.22 & 0.11 & 0.22 & 0.19 & 0.12 & 0.23 \\
\hline $\mathrm{NO}_{3}^{-}$ & $(\mathrm{mmol} / \mathrm{L})$ & 0.000 & 0.000 & 0.000 & 0.000 & 0.000 & 0.003 & 0.000 & 0.013 & 0.011 & 0.005 \\
\hline $\mathrm{SO}_{4} / \mathrm{Ca}$ & & 1.9 & 1.2 & 1.1 & 1.4 & 1.2 & 1.4 & 1.3 & 1.3 & 1.4 & 1.4 \\
\hline Electrical balance $\%$ & & 3.3 & 0.7 & -3.3 & -1.2 & -3.2 & 1.8 & 2.8 & 2.6 & 0.0 & 1.0 \\
\hline \multicolumn{12}{|l|}{ Calculated values } \\
\hline $\mathrm{Fe}$ & $(\mathrm{mmol} / \mathrm{L})$ & $2 \mathrm{E}-6$ & $2 \mathrm{E}-06$ & $8 \mathrm{E}-06$ & $2 \mathrm{E}-05$ & 3E-06 & $4 \mathrm{E}-06$ & $3 \mathrm{E}-06$ & $4 \mathrm{E}-06$ & $4 \mathrm{E}-06$ & $3 \mathrm{E}-06$ \\
\hline $\mathrm{PCO}_{2}$ & $(\log (\operatorname{atm}))$ & -3.36 & -2.75 & -2.58 & -2.51 & -3.22 & -2.91 & -3.13 & -2.50 & -3.35 & -3.29 \\
\hline $\mathrm{Eh}$ & $(\mathrm{mV} / \mathrm{H} 2)$ & 550 & 457 & 552 & 562 & 542 & 566 & 479 & 513 & 525 & 412 \\
\hline SI pyrite & & -181 & -184 & -192 & -185 & -168 & -188 & -176 & -179 & -179 & -161 \\
\hline Phlogopite + Kmica & $(\mathrm{mmol} / \mathrm{L})$ & 0.13 & 0.13 & 0.13 & 0.17 & 0.2 & 0.72 & 0.2 & 0.17 & 0.1 & 0.21 \\
\hline Dolomite & $(\mathrm{mmol} / \mathrm{L})$ & 4.00 & 1.7 & 1.57 & 1.62 & 1.67 & 0.13 & 1.73 & 1.99 & 2.91 & 1.31 \\
\hline Calcite & $(\mathrm{mmol} / \mathrm{L})$ & -0.9 & -2.96 & -1.15 & -2.66 & -2.69 & 0 & -0.81 & -1.16 & -3.13 & -1.7 \\
\hline Gibbsite & $(\mathrm{mmol} / \mathrm{L})$ & -3.72 & -4.69 & -3.25 & -4.31 & -4.05 & -3.84 & -4.28 & -3.91 & -3.73 & -4.8 \\
\hline $\mathrm{Fe}(\mathrm{OH})_{3}(\mathrm{a})$ & $(\mathrm{mmol} / \mathrm{L})$ & -1.51 & -1.83 & -1.28 & -1.27 & -1.23 & -1.66 & -1.8 & -1.73 & -1.53 & -1.49 \\
\hline $\mathrm{O}_{2(\mathrm{~g})}$ & $(\mathrm{mmol} / \mathrm{L})$ & 5.62 & 2.49 & 4.78 & 4.77 & 4.62 & 6.23 & 6.75 & 6.5 & 5.74 & 5.62 \\
\hline $\mathrm{CO}_{2(\mathrm{~g})}$ & $(\mathrm{mmol} / \mathrm{L})$ & 0 & 0 & 0 & 0 & 0 & 0 & 0 & 0 & 0 & 0 \\
\hline Gneiss $=\Sigma$ Pla.+ Phlo & $(\mathrm{mmol} / \mathrm{L})$ & 2.13 & 2.82 & 1.96 & 2.6 & 2.47 & 2.39 & 2.6 & 2.37 & 2.23 & 2.91 \\
\hline Py/Gneiss & $(\mathrm{mmol} / \mathrm{L})$ & 0.7371 & 0.234 & 0.6531 & 0.4885 & 0.498 & 0.6946 & 0.6923 & 0.73 & 0.6861 & 0.5151 \\
\hline
\end{tabular}




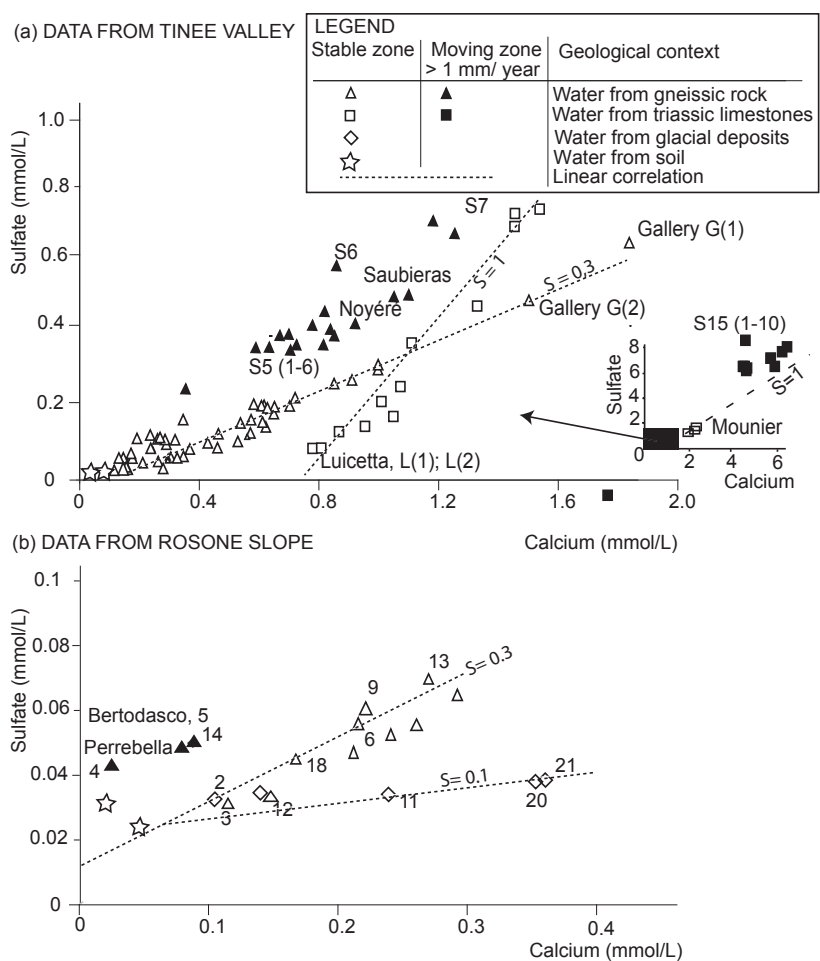

Fig. 3. Spatial variability of solute concentration measured in the springs of gneiss rock aquifers: (a) in the Tinée valley ( S15 is in an insert) and (b) in the Rosone slope. The symbol form is related to the geological context, the black symbols are related to spring draining a unstable slope.

\section{Modelling of water rock interaction}

\subsection{Modelling working assumptions}

Speciation modelling of the rock-water interactions were performed with the PHREEQC code and the integrated wateq $4 \mathrm{f}$ database (Parkust and Appelo, 2004). The model gneiss rock compositions is based on referenced analysis (see previous section), except that Biotite was replaced by Phlogopite, i.e. the end member of the Phlogopite - Siderophillite solidsolution system, as solubility data for the latter compound was not available.

The soil water is considered representing the initial chemical composition of the flowing groundwater (Guglielmi et al., 2002). The mean bicarbonate concentrations of the four samples is $0.1 \mathrm{mmol} / \mathrm{L} \pm 0.1$ (analysis Soil in Table 2), the $\mathrm{pH}$ is $5.5 \pm 0,5$. In these steep slopes, the soil is poorly developed and soil water represents the initial chemical composition of the flowing groundwater (Guglielmi et al., 2002). Once infiltrated into the deeper fractures, the organic matter is considered entirely degraded and/or outfiltered and not being further supplied. This modelling hypothesis is supported by the oxygenated conditions found in all spring waters (Table 2, Eh data).

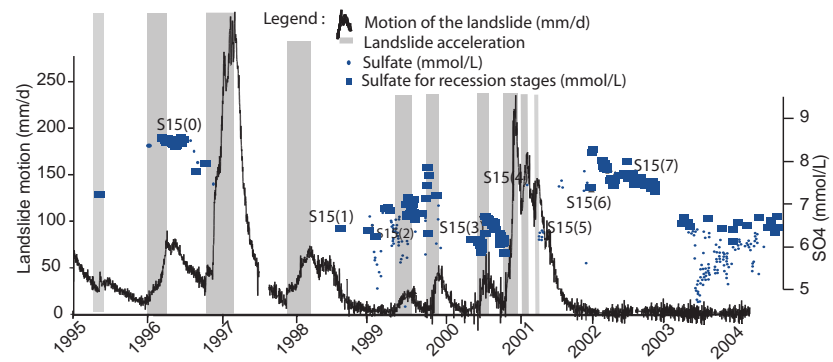

Fig. 4. Temporal evolution of the sulfate concentration measured in a spring draining from an active unstable area (La Clapière landslide). The circles present the whole measurement. The squares present the measurements realized when nitrate concentration is null (recession stage). The sulfates, changed during the recession stage, are related with the landslide velocity (strong accelerations are grey shaded). Sulfate concentration of year 1998 are not exploitable. The $S 15(1,2, \ldots)$ annotations, refer to complete analysis of the $\mathrm{S} 15$ trough time, presented in the Table 3.

In such a system, the gneiss rock dissolution becomes the dominant process. The $\mathrm{pH}$ will gradually increase when the primary minerals consume $\mathrm{H}^{+}$ions. The increasing $\mathrm{pH}$ leads finally to precipitation of insoluble mineral phases, and especially the precipitation of $\mathrm{Al}(\mathrm{OH})_{3}$ and $\mathrm{Fe}(\mathrm{OH})_{3}$. It can be deduced from Table 1 that seven, two, or respectively one $\mathrm{H}^{+}$ moles are consumed when dissolving one molecular unit of phlogopite, anorthite and albite or Kmica (in considering that Silica is released as silicic acid $\mathrm{Si}(\mathrm{OH})_{4}$, and $\mathrm{Al}$ as $\left.\mathrm{Al}(\mathrm{OH})_{3}\right)$.

This basis of the hypothesis is inferred from the experimental data set, as all spring water have higher $\mathrm{pH}$ and higher ion concentrations than the soil water. In concordance to field observations (Fig. 2), Fe-oxide and Al-oxyde precipitation will occur. To note that the few $\mathrm{OH}^{-}$ions bound to dissolved $\mathrm{Al}(\mathrm{OH})_{4}^{-}$and $\mathrm{Fe}(\mathrm{OH})_{4}^{-}$species are not significant compared to the mass of dissolved $\mathrm{OH}^{-}$ions.

The increase in $\mathrm{pH}$ will also lead to a decrease of the $\mathrm{PCO}_{2}$ through the transformation of dissolved $\mathrm{CO}_{2}$ into $\mathrm{HCO}_{3}^{-}$. This mechanism, associated with $\mathrm{Ca}$ from the dissolution of primary minerals, may lead to calcite precipitation. Table 2 shows that 2 of the 13 reported springs have calcite saturation index $\geq 0.5$. The observed calcite in fractures and the other study on hydrochemistry of gneiss rock (Appello and Postma, 1996) indicates that calcite precipitation occurs in these systems and calcite was added as an equilibrium phase in the model.

The presence of pyrite, attested from field observations, is considered to be a source of $\mathrm{Fe}$ ions. The oxidation to sulfate and $\mathrm{Fe}^{+3}$, with the associated precipitation of $\mathrm{Fe}(\mathrm{OH})_{3}$ is a strongly proton-producing process (Eq. 1)

$\mathrm{FeS}_{2}+3.75 \mathrm{O}_{2}+3.5 \mathrm{H}_{2} \mathrm{O} \Leftrightarrow \mathrm{Fe}(\mathrm{OH})_{3}+2 \mathrm{SO}_{4}^{-2}+4 \mathrm{H}^{+}$

Finally, the presence of Gypsum is also attested in the Triassic deposits. Gypsum is add in the model only for S15 presented in Table 3. This mineral increases $\left[\mathrm{SO}_{4}^{-2}\right]$ and 
increases the saturation index of calcite, i.e. promotes its precipitation. Concerning $\mathrm{pH}$, the dissolution of the primary minerals increases $\mathrm{pH}$, whereas precipitation of calcite (through deprotonation of $\mathrm{HCO}_{3}^{-}$ions), Oxidation of pyrite and precipitation of iron oxides decreases the $\mathrm{pH}$. Dissolution of gypsum has no direct effect on $\mathrm{pH}$.

The source and sink terms of individual ions can be outlined as follows: $\mathrm{SO}_{4}^{-2}$ is provided from pyrite and gypsum. silica, $\mathrm{Al}$ and $\mathrm{OH}^{-}$are finally released from all primary minerals. On the side of precipitation, calcite binds excess $\mathrm{Ca}$ and alkalinity, $\mathrm{Fe}$ precipitates as $\mathrm{Fe}(\mathrm{OH})_{3}$, and $\mathrm{Al}$ precipitates as $\mathrm{Al}(\mathrm{OH})_{3}$. As silica gel and amorphous phases saturation index are negatives, and as quartz and phlogopite have low kinetics of precipitation, these minerals can be oversaturated.

\subsection{Inverse modelling}

Dissolved ions in spring water are considered originating from rocks and gazes. The necessary quantities of minerals and gases to be dissolved in the soil water to obtain the spring water composition, were obtained from inverse modelling with PHREEQC, by specifying the measured concentration of major ions $\left(\mathrm{Ca}, \mathrm{Mg}, \mathrm{K}, \mathrm{Na}, \mathrm{SO}_{4}, \mathrm{Cl}, \mathrm{NO}_{3}\right.$, alkalinity), $\mathrm{pH}$, temperature (fixed to $8^{\circ} \mathrm{C}$ for all conditions) of both, the soil and the target spring water. The minerals considered for dissolution in the water are halite (for $\mathrm{Cl}$ ), quartz, plagioclase, phlogopite, Kmica and pyrite. Minerals considered potentially precipitating dependent on the calculated saturation index were calcite, dolomite, ferrihydrite, gibbsite. The model considers $\mathrm{CO}_{2}$ and $\mathrm{O}_{2}$ as two dissolved phases. The calculated amount of consumed gas will open the discussion about open/close reservoir conditions. The proton balances are involved in these calculations. The calculations are applied to the 6 major springs (13 samples) draining gneiss fractures from the two study valleys (Table 2). The uncertainty on the calculated ionic balance, is fixed to $15 \%$ because the model is a simplification using only 5 minerals to describe the gneiss rock.

For the S15 spring (10 samples; approximately one per year) the same minerals list are considered, adding dolomite, and gypsum. The modelled amounts of gas and mineral dissolved needed to reproduce the spring water compositions are reported in Table 3.

The system is considered at the equilibrium, however, the spring water composition is controlled by a continuous dissolution process. The equilibrium model results represents a momentum analysis of kinetically driven reaction during the transfer of water in the subsurface, which did not arrive at its end.

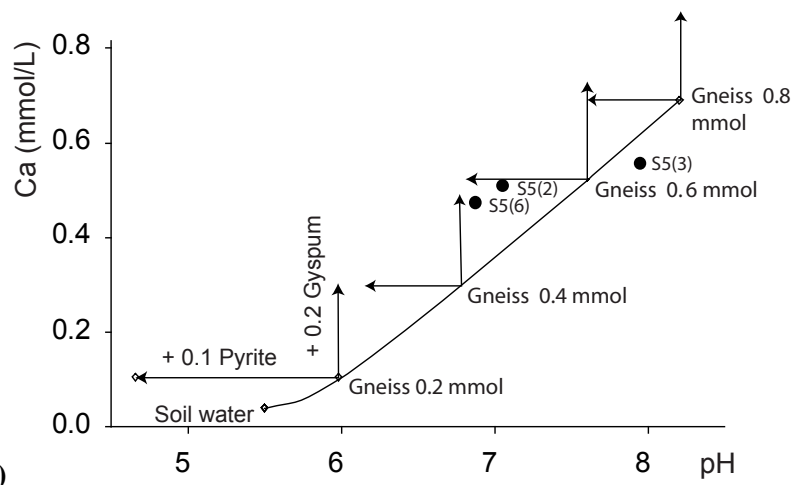

(a)

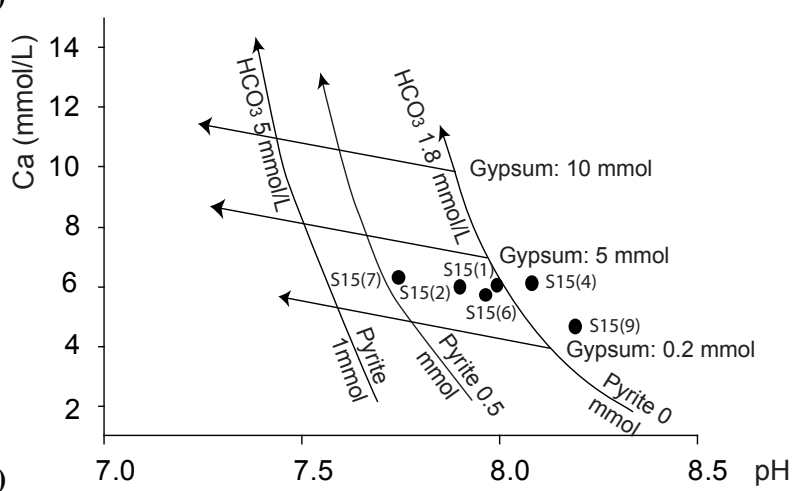

Fig. 5. Calculated evolution of $\mathrm{pH}$ and calcium content related to a $0.2 \mathrm{mmol} / \mathrm{L}$ sulfate increase in water flowing in gneiss rock and comparison with field measurements. (a) evolution in $\mathrm{pH}$ and $\mathrm{Ca}^{2+}$ for dissolving gneiss rock (continuously increasing basis curve starting from the soil water), with or without contributions from pyrite and gypsum in calcite undersaturation conditions. Sulfate increases are induced from either a $0.1 \mathrm{mmol}$ of pyrite, either a $0.2 \mathrm{mmol} / \mathrm{L}$ of gypsum dissolution, in a $\mathrm{Phl}-$ ogopite + Plagioclase contents fixed to $0.2,0.4,0.6,0.8 \mathrm{mmol} / \mathrm{L}$, in an undersaturated water in respect to calcite. The model is confronted to S5 springs measurements dissolving approximately $0.6 \mathrm{mmol} / \mathrm{L}$ of gneiss rock, presented in Table 2. (b) sulfate increases are induced from either a $0.1 \mathrm{mmol}$ of pyrite dissolution in gneiss rock, either a $2 \mathrm{mmol} / \mathrm{L}$ of gypsum dissolution in gneiss rock buffered context (fixed alkalinity $=1 \mathrm{mmol} / \mathrm{L}$, phlogopite $+\mathrm{K}$ mica + albite + anorthite content $=0.2 \mathrm{mmol} / \mathrm{L}$ ) in saturated water in respect to calcite. The model is confronted with $\mathrm{S} 15$ spring measurements presented in Table 3.

\subsection{Dominant processes controlling the water quality}

\subsubsection{Origin of sulfates in silicate system water deduced from $\mathrm{pH}$ buffering processes}

Figure 5a shows the results of a direct model used to discuss the inverse modelling. The evolution in $\mathrm{pH}$ and $\mathrm{Ca}^{2+}$ for variable amounts of dissolved gneiss rock (continuously increasing basis curve starting from the soil water), with or without contributions from dissolved pyrite and gypsum in calcite undersaturation conditions. Sulfate increases are induced from either a $0.1 \mathrm{mmol} / \mathrm{L}$ of pyrite, 
or from a $0.2 \mathrm{mmol} / \mathrm{L}$ of gypsum dissolution, in a Phlogopite + Kmica + plagioclase contents, respectively, fixed to $0.2,0.4,0.6,0.8 \mathrm{mmol} / \mathrm{L}$. The dissolution of equivalent amounts of sulfate from pyrite or gypsum results in a decrease of $\mathrm{pH}$ (in the case of pyrite) or in an increase of $\left[\mathrm{Ca}^{2+}\right]$ (in the case of Gypsum). These different effects allow us to determine the origin of sulfate (pyrite versus gypsum) in the S5 spring. The inversed modelling suggests that $\mathrm{S} 5(2), \mathrm{S} 5(3)$ and $\mathrm{S} 5(6)$ dissolve $0.6 \mathrm{mmol} / \mathrm{L}$ of gneiss rock (Table 2). These data plotted in Fig. 5a shows that for fixed amounts of dissolved gneiss rock the spring water $\mathrm{pH}$ decreases with time but not $\left[\mathrm{Ca}^{2+}\right]$; more precisely between 0.1 and $0.8 \mathrm{mmol} / \mathrm{L}$ of pyrite needs to be dissolved, versus less than $0.1 \mathrm{mmol} / \mathrm{L}$ of Gypsum. The observed changes through time in sulfate concentration (S5(2), S5(3) and S5(6)) plotted in Fig. 5 indicate that the sulfate essentially changes originates from pyrite.

The interference between gypsum and pyrite, in calcite saturated conditions observed in the S15 spring, are more complex (Fig. 5b). Dissolved $\mathrm{Ca}^{2+}$ will partly contribute to increase $\left[\mathrm{Ca}^{2+}\right]$, and partly precipitate as calcite, decreasing by the way the alkalinity and the $\mathrm{pH}$ (through deprotonation of precipitating $\mathrm{HCO}_{3}^{-}$ions). In Fig. 5b, Gypsum dissolution curves are thus no longer vertical. Concerning pyrite, the protons released (Eq. 1) will (as for Gypsum) displace the saturation $\mathrm{pH}$ of calcite to lower $\mathrm{pH}$ values, which means dissolution of calcite. In this case, both $\left[\mathrm{Ca}^{2+}\right]$ and alkalinity increase, different to Gypsum dissolution. Parts of the protons contribute to lower the $\mathrm{pH}$, and parts contribute to protonate the $\mathrm{CO}_{3}^{-2}$ ions released to the solution from calcite. Thus, pyrite dissolution curves in Fig. $5 b$ have also a negative slope. The S15 spring, saturated with respect to calcite, flows through gypsum and calcite. The sulfate content is very high $(8 \mathrm{mmol} / \mathrm{L})$. The $\mathrm{pH}$ versus $\mathrm{Ca}$ plot of the $\mathrm{S} 15$ time series (Fig. 5b) shows that 2 to $5 \mathrm{mmol}$ of Gypsum and 0 to $0.5 \mathrm{mmol} / \mathrm{L}$ of pyrite contributed to the sulfate measured in the spring. This shows that Gypsum dominantly contributed to the sulfate composition in this case, but pyrite is necessary to explain the recorded time evolution.

\subsection{2 $\mathrm{O}_{2}$ and $\mathrm{CO}_{2}$ conditions, and implications for open/closed model assumption}

In the model, the introduced pyrite is entirely oxidized, as an excess oxygen concentration is introduced. This ensures that oxygenated conditions prevail at the spring outlet as experimentally determined (Table 2 and 3). A priori this introduced "reactive pyrite" represents only a minor fraction of the FeS minerals existing in the field. Potentially, much more pyrite may be really present, but associated with an insufficient contact time with water and/or surface area. The very low saturation index of the pyrite (from -160 to -200 ) for a redox reaction confirm that pyrite is controlled by kinetics processes (Stefansson et al., 2005).
Following the pyrite oxidation (Eq. 1), 3.75 oxygen atoms are needed to oxidise two sulphur atoms to sulfate. $\mathrm{O}_{2}$ saturated water at $5^{\circ} \mathrm{C}\left(\right.$ Saturation $\left.\left[\mathrm{O}_{2}\right]_{\mathrm{aq}}=0.4 \mathrm{mmol} / \mathrm{L}\right)$ may thus produce a maximum of $0.21 \mathrm{mmol} / \mathrm{L}$ sulfate from pyrite in a closed system. Most of the inversed $\mathrm{O}_{2}$ values presented in Table 2 exceed this theoretical value by a factor of one or two. This means that the system is open for oxygen. Some surface oxygen supposedly diffuses into the groundwater, thus, contributing to enhance the dissolved oxygen content needed for the oxidation of pyrite. Here, the groundwater flows mainly in the unsaturated zone in contact with gases (Binet et al., 2007b). Hydrogeological context is coherent with an open system. Note that the regular decrease of sulfate (Fig. 4) between 2002 and 2003 may discard a seasonal evolution of $\mathrm{O}_{2}$ or $\mathrm{CO}_{2}$ pressures or of the temperature that controlled the pyrite oxidation. In other areas, the dissolution of pyrite is insensitive to seasonal changes (Domenech et al., 2002).

$\mathrm{PCO}_{2}$ values at the spring outlet (Table 2 and 3 ) range between -3.32 and -2.7 and are superior to the atmospheric $\mathrm{PCO}_{2}$ pressure $\left(\mathrm{PCO}_{2}=10^{-3.5} \mathrm{~atm}\right.$.). In the given system of open fractures, we consider that the system is opened to the atmosphere. This means that $\mathrm{CO}_{2}$ (together with oxygen) diffuses continuously to the groundwater providing the necessary acid for the neutralization of the base generated through the dissolution of the gneiss rock. This generates the alkalinity (i.e. the $\mathrm{HCO}_{3}^{-}$concentration) measured at the spring outlet. The Inversed modelling indicates that low $\mathrm{CO}_{2}$ exchanges with the atmosphere occurred. Realized a model without $\mathrm{CO}_{2(\mathrm{~g})}$, to simulate a closed system do not modify the calculated solutions presented in Table 2 . The soil alkalinity input $(0.1 \mathrm{mmol} / \mathrm{L})$ is sufficient to explain the bicarbonates evolution with the $\mathrm{pH}$ increase, but errors range caused by the alkalinity measurements $( \pm 0.1)$ do not enable to exclude possible $\mathrm{CO}_{2}$ exchanges with the atmosphere.

More importantly, this shows that respiration processes observed in soil, did not occur in the open fractures as these processes are known to disturb the groundwater $\mathrm{PCO}_{2}$ values compared to the atmospheric pressure. This indicates that the organic matter of soil water was effectively outfiltered and/or entirely respirated into the soil before flowing through the fractures.

\subsection{Pyrite availability in unstable areas}

Table 2 and 3 show the amounts of dissolved minerals used to explain the groundwater chemistry. Plagioclase and phlogopite well explain the water chemistry acquisition (Table 2) and are considered the main reactive minerals in gneiss rock. The sum of these minerals is considered to represent the amount of dissolved gneiss rock. The chemistry of water presented in Table 2 is explained with a dissolution from 0.062 to $2,73 \mathrm{mmol}$ of gneiss rock and from 0.008 to $0.38 \mathrm{mmol}$ of pyrite per litre. The water from S15 dissolves from 1.9 to $2.9 \mathrm{mmol}$ of gneiss rock, 2.9 to $5.7 \mathrm{mmol}$ of Gypsum, 1.7 to $4 \mathrm{mmol}$ of dolomite and 1.5 to $1.8 \mathrm{mmol}$ of pyrite per litre. 
The dissolved amount of pyrite normed to the gneiss rock amount $(\mathrm{Py} / \mathrm{Gn})$ is an indicator of the relative pyrite weathering rate. (Table 2 and 3). The Py/Gn ratio range from 0.04 to 0.13 in a stable aquifer and from 0.16 to 0.74 in unstable aquifers. The significant difference in the relative Py/Gn ratio suggests that the relative weathering rate of the pyrite is higher in the active fractures.

\section{Discussion}

\subsection{Relationship between physical erosion and chemical weathering}

$\mathrm{SO}_{4}$ time evolution could originate from a mix process, with water from a pyrite rich reservoir. However, the other ions in the water are not correlated with the accelerations. When the sulfate concentrations decrease, the $\mathrm{Mg}, \mathrm{Cl}, \mathrm{Ca}$ and $\mathrm{HCO}_{3}$ concentrations can increase (for example see S15(7) and S15(8) in Table 3) or can decrease (see S15(0) and S15(1)). Thus, the mix process between water from the landslide and a sulfate-rich water can be reasonably discarded.

To discuss the origin of $\mathrm{SO}_{4}$ time evolution requires taking into account an internal modification of the dissolution rate of the pyrite correlated with landslide velocity. Within the fractures, the crystalline rock materials were found to be covered by iron oxide coatings (Fig. 2c) inferred weathered.

Sulfate anomalies were observed in all the water flowing through active landslides in the two study valleys (Fig. 3). These sulfate increases were observed after 5 landslide accelerations, and indicate that a mechanical deformation can (re) activate sulfate production. Thus, a mechanical effect can refresh the surfaces, reinitialize the dissolution or create new fresh fractures (Fig. 2b). This mechanical effect can be linked to mechanical deformation of the slope, characterised in these valleys by complex progressive failure propagation (Barla and Chiriotti, 1996).

During laboratory experiments of pyrite leaching, it appears that the dissolution rate decreases with time (Williamson and Rimstidt, 1994; Igarashi et al., 2003; Weisener et al., 2003). With time, the aging of mineral decreases the contact surface and the original behaviour of pyrite dissolution cannot be re-established (Jerz and Rimstidt, 2004). For instance, with a 10 year observation scale, modifications of the groundwater chemistry in an acid moorland in the Welsh Uplands is attributed to a decrease in the weathering rate of pyrite (Forti et al., 1996). On the other side, at the continental scale, a theoretical model coupling chemical weathering and physical erosion in landslidedominated landscapes is proposed to explain the refreshment of the weathering rate (Gabet, 2007). Here, long-term decrease of the weathering rate and the theoretical refreshment are suggested at the landslide scale.

\subsection{Implication for landslide management}

A comparison of the weathering rates shows the possibility to localize current unstable areas with instantaneous measurements. This method enables us to demonstrate the presence of a current unstable zones in the catchment. In these unstable mountainous contexts, the catchments of subsurface flows are localized. The water infiltrates in the upper part of open fractures and a part of it discharges downhill from the bottom of these fractures (Binet et al., 2007). By performing sampling very close to the potential unstable area, it is possible to deduce if the sampled zone is moving or not.

If a potentially unstable slope is monitored, water chemistry is like a syn-deformation signal that can be used to recorded the fracture growing or the sliding evolution. With time, the fracture growing can lead to a catastrophic rupture (Scavia, 1995) and water chemistry can be a help to the prediction of this catastrophic rupture.

Stable zones record a 0.13 to $0.4 \mathrm{Py} / \mathrm{Gn}$ ratio. In the moving zones, $\mathrm{Py} / \mathrm{Gn}$ ratio ranges between 0.16 to 0.74 . Considering error range in the weathering rate values, a 0.15 value can be considered as a threshold value to discriminate between stable and unstable area. This ratio is establish from two different alpine valleys (Tinée and Rosone). Extrapolate this ratio for other slopes means that the water/rock interaction surfaces and the weathering state in the stable areas are similar. Such hypothesis can be tested using a well-know stable aquifer before testing the potentially unstable zones.

In the toppled area of the S5 spring, the two high ratios of the relative weathering rates of pyrite ( 0.4 for 1998 and 2004) suggest that the two last accelerations of the La Clapière landslide (1997 and 2000) have affected the entire hillslope. In this area, mm/year displacements are estimated by stability calculations (Guglielmi et al., 2005). The hydrochemical signature is produced even from slow ( $\mathrm{mm} /$ year) and low magnitude (toppling) deformations.

The accelerations and the ruptures in the rock deformation have a very short time scale (form a second to a day).The changes in chemical signature of groundwater are related to transport of water (from a day to months in these subsurface context). If the dissolution rate is changed, it will take some time for sulfate to reach a new steady state concentration. No experimental data is available about the refreshed rates of pyrite. Figure 4 suggests that the changes in transport delay and in the dissolution rates take from 1 to 6 month to reach the spring.

The rock deformations are often drive by crack propagations producing precursor slow movements (Scavia, 1995) that can be recorded by the water chemistry. In the case where we can sample water close to (or in) a deformation area, the transport delay will be reduced and precursor slow movements could be detected. 


\section{Conclusions}

Wet chemical analysis, from the Orco and the Tinée valleys (Western Italy and Southern France) were performed. Some of these springs drain currently active gravitational slope deformations. The groundwater sulfate concentrations increased from 0.1 to $1 \mathrm{mmol} / \mathrm{L}$ in the weeks following major displacement periods of a landslide. This study shows that unstable areas may potentially be detected by associating major ions analysis to inverse modelling of chemical equilibria: the calculation of the dissolved pyrite to dissolved gneiss rock ratio allows an unambiguous determination of the water flowing through unstable zones. Here, gneiss rock and gypsum are the principal dissolving compound, and pyrite is the minor compound, which is rapidly dissolved, and consequently increasingly present in case its reactive surface is "refreshed" through the movement of rock masses. The discrimination of stable and unstable areas is possible even in the case of slow (mm/year) and low magnitude deformations. This result opens an interesting perspective for a cost-effective follow-up of sliding or friction dynamics in the landslides or in the seismic and aseismic faults.

Acknowledgements. This work was supported by the RETINA project, the French INSU SAMOA project and the Franco Italian University. We sincerely thank the CETE of Nice and the Arpa of Torino for their collaborations. A part of this work was realized in the Mercantour National Parc, under authorization of the direction. The authors sincerely thank Pr Olivier Fabbri and the anonymous referees for their constructive comments. This work could not have been achieved without the technical support of Maguerite Goetghebeur and Bruno Regent. Grazie mille!

Edited by: A. Guadagnini

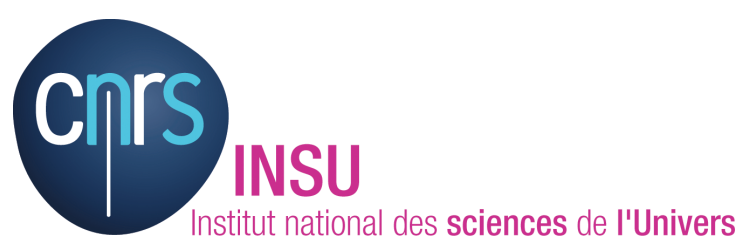

The publication of this article is financed by CNRS-INSU.

\section{References}

Appelo, C. A. J. and Postma, D.: Geochemistry, groundwater and pollution, Book A. A. Balkema, Rotterdam, 1996.

Agliardi, F., Crosta, G., and Zanchi, A.: Structural constraints on deep-seated slope deformation kinematics, Eng. Geol., 59, 83$102,1996$.

Amatruda, G., Campus, S., Castelli, M., Piane, L., Forlatti, F., Morelli, M., Paro, L., Piana, F., Pirulli, M., Ramasco, M., and Scavia, C.: Identification And Mitigation Of Large Landslide Risks In Europe: Advances In Risk Assessment, edited by: Bonnard, Ch., Forlati, F., and Scavia, C., A. A. Balkema, Imiriland project, Torino, 2004
Binet, S., Mudry, J., Scavia, C., Campus, S., Bertrand, C., and Guglielmi, Y.: In situ characterization of flows in a fractured unstable slope, Geomorphology, 86, 193-203, 2007a.

Binet, S., Guglielmi, Y., Bertrand, C., and Mudry, J.: Unstable rock slope hydrogeology: insights from the large-scale study of the western Argentera-Mercantour hillslopes (South-Eastern France), B. Soc. Geol. Fr., 178, 159-168, 2007b.

Binet, S., Jomard, H., Lebourg, T., Guglielmi, Y., Tric, E., Bertrand, C., and Mudry, J.: Experimental analysis of groundwater flow through a landslide slip surface using natural and artificial water chemical tracers, Hydrol. Process., 21, 3463-3672, 2007c.

Barla, G. and Chiriotti, E.: Insights into the behaviour of the Large Deep Seat Gravitational Slope Deformation of Rosone, in the Piemont Region (Italy), Int. J. Rock Mech. Min., 33, 242-242, 1996.

Bonzanigo, L., Eberhart, E., and Loew, S.: Hydromechanical factors controlling the crfeeping Campo Vallemaggia, in: Symposium of landslides, causes, impacts and countermeasures, edited by: UEF, Davos, 13-22, 2001.

Cappa, F., Guglielmi, Y., Soukatchoff, V. M., Mudry, J., Bertrand, C., and Charmoille, A.: Hydromechanical modelling of a large moving rock slope inferred from slope levelling coupled to spring long-term hydrochemical monitoring: example of the La Clapiere landslide (Southern Alps, France), J. Hydrol., 291, 6790, 2004.

Casson, B., Delacourt, C., Baratoux, D., and Allemand, P.: Seventeen years of the "La Clapiere" landslide evolution analyzed from ortho-rectified aerial photographs, Eng. Geol., 68, 123-139, 2003.

Domenech, C., De Pablo, J., and Ayora, C.: Oxidative dissolution of pyritic sludge from the Aznalcollar mine (SW Spain), Chem. Geol., 190, 339-353, 2002.

Faure-Muret, A.: Etude géologique sur le massif de l'Argentera Mercantour et ses enveloppes sédimentaires: Mémoire à l'explication de la carte géologique détaillée, Thesis Paris, Mem.serv. Carte geol, France (ed), 336, 1955.

Féraud, J., Picot, P., Pierrot R., and Vernet, J.: Métallogénie: sur la découverte de scheelite, cassitérite, bismuthinite et molydénite dans les gîtes à arsénopyrite du massif de l'Argentera, Conséquences métallogénétiques et pétrogénétiques, Comptes Rendus de l'Académie des sciences, Paris, 280, 2179-2182, 1975.

Follacci, J. P.: Les mouvements du versant de la Clapière à Saint Etienne de Tinée (Alpes Maritimes), Bulletin des Laboratoires des Ponts et Chaussées, 150, 107-109, 1987.

Forlati, F., Gioda G., and Scavia, C.: Finite element analysis of a deep-seated slope deformation, Rock Mech. Rock Eng., 34, 135-159, 2001.

Forti, M. C., Neal, C., and Robson, A. J.: Modelling the long-term changes in stream, soil and ground water chemistry for an acid moorland in the Welsh uplands: the influence of variations in chemical weathering, Sci. Total Environ., 180, 187-200, 1996.

Gabet, E. J.: A theoretical model coupling chemical weathering and physical erosion in landslide-dominated landscapes, Earth Planet. Sc. Lett., 264, 259-265, 2007.

Guglielmi, Y., Bertrand, C., Compagnon, F., Follacci, J. P., and Mudry, J.: Acquisition of water chemistry in a mobile fissured basement massif: its role in the hydrogeological knowledge of the La Clapiere landslide (Mercantour massif, southern Alps, 
France), J. Hydrol., 229, 138-148, 2000.

Guglielmi, Y., Vengeon, J., Bertrand, C., Mudry, J., Follacci, J., and Giraud, A.: Hydrogeochemistry: an investigation tool to evaluate infiltration into large moving rock masses (case study of the La Clapière and Séchilienne alpine landslides), Bull. Eng. Geol. Env., 61, 311-324, 2002.

Guglielmi, Y., Cappa, F., and Binet, S.: Coupling between hydrogeology and deformation of mountainous rock slopes: Insights from La Clapiere area (southern Alps, France), C. R. Geosci., 337, 1154-1163, 2005.

Gunzburger, Y. and Laumonier, B.: A tectonic origin for the fold underlying the Clapiere landslide (NW Argentera-Mercantour massif, Southern Alps, France) deduced from an analysis of fractures, C. R. Geosci., 334, 415-422, 2002.

Igarashi, T., Hataya, R., and Oyama, T.: Estimation of pyrite oxidation rate by sulfate ion discharged from a catchment, J. Geochem. Explor., 77, 151-165, 2003.

Jerz, J. K. and Rimstidt, J. D.: Pyrite oxidation in moist air, Geochim. Cosmochim. Ac., 68, 701-714, 2004.

Julian, M. and Anthony, E.: Aspects of landslide activity in the Mercantour Massif and the French Riviera, southeastern France, Geomorphology, 15, 275-289, 1996.

Keefer, D., Wilson, R. C., Mark, R. K., Brabb, E. E., Browm, W. M., Ellen, S. D., Harp, E. L., Wieczorek, G. F., Alger, C. S., and Zatkin, R. S.: Real-Time Landslide Warning During Heavy Rainfall, Science, 13, 921-925, 1987.
Mazeran, R. and Féraud, J.: Sur la thermoluminescence des quartz filoniens à BPGC du massif de l'Argentera, Mise en évidence du caractère polyphasé de ces minéralisations, Comptes Rendus de l'Académie des sciences, Paris, 278, 1147-1150, 1974.

Mudry, J.: Chemical mass flow vs. discharge and the functioning of karst aquifers, J. Hydrol., 120, 283-294, 1990.

Parkust, D. L. and Appelo, C. A. J.: PhreeQC2 user's manuel and programm. Water-Resources Investigations Report, edited by: US Geological Survey, 2004.

Scavia, C.: A method for the study of crack propagation in rock structures, Géotechnique, 45, 447-463, 1995.

Stefansson, A., Arnorsson, S., and Sveinbjornsdottir, A. E.: Redox reactions and potentials in natural waters at disequilibrium, Chem. Geol., 221, 289-311, 2005.

Tullen, P.: Méthodes d'analyses du fonctionnement hydrogéologique des versant instables, PhD Thesis, ed. EPFL, Lausanne, 2002.

Vengeon, J. M.: Déformation et rupture des versants en terrain metamorphique anisotrope, Apport de l'étude des ruines de Séchilienne, PhD Thesis, ed. University of Grenoble 1, Grenoble, 1998.

Weisener, C. G., Smart, R. S. T. C., and Gerson, A. R.: Kinetics and mechanisms of the leaching of low Fe sphalerite, Geochim. Cosmochim. Ac., 67, 823-830, 2003.

Williamson, M. A. and Rimstidt, J. D.: The kinetics and electrochemical rate-determining step of aqueous pyrite oxidation, Geochim. Cosmochim. Ac., 58, 5443-5454, 1994. 